\title{
Effects of Glyphosate on Eucalyptus After its Application on Brachiaria (Signal) Grass
}

\author{
Edicarlos Batista de Castro $^{1}$ (D), Caio Antonio Carbonari ${ }^{1}$ (D), \\ Edivaldo Domingues Velini ${ }^{1}$ (D), Gabrielle de Castro Macedo ${ }^{1}$ (1), \\ Plínio Saulo Simões ${ }^{1}$ \\ ${ }^{1}$ Universidade Estadual Paulista Júlio de Mesquita Filho (Unesp), Botucatu, SP, Brasil
}

\begin{abstract}
The objective of this article was to evaluate the effects of glyphosate on the initial development of eucalyptus (Eucalyptus urograndis) after its application on brachiaria (signal) grass plants (Brachiaria decumbens). The experiment was conducted in a greenhouse in a completely randomized design. Glyphosate, aminomethylphosphonic acid (AMPA) and shikimic acid concentrations were determined, along with an intoxication evaluation of the eucalyptus plant pointers and dry mass of the plants. Glyphosate was detected in eucalyptus plants after its application on $B$. decumbens plants, but the eucalyptus plants only presented low intoxication levels in the pointer's leaves. No AMPA was detected in eucalyptus leaves, and only a dose of 1,440 g e.a. ha $^{-1}$ of glyphosate reduced the total dry mass of eucalyptus plants. Glyphosate has the potential to cause intoxication in the crop when applied to adjacent plants.
\end{abstract}

Keywords: absorption, Brachiaria decumbens, Eucalyptus urograndis, herbicide, interference. 


\section{INTRODUCTION AND OBJECTIVES}

The Brazilian forestry sector has great importance for the country's economy, since its significant growth has been one of the factors responsible for the national trade surplus. In Brazil, reforested area corresponds to 7.74 million planted hectares, with approximately $71.9 \%$ of this area cultivated with the Eucalyptus genus (IBÁ, 2015). Among the limiting factors of eucalyptus productivity, weed interference is worth highlighting. Weeds compete for available resources in the environment, and if not controlled at the right time they reduce forest productivity, making crop management difficult and increasing the risk of fire (Tiburcio et al., 2012).

To reduce the damage caused by weed interference, management in forest areas is predominantly done by chemical control. Glyphosate (N-phosphonomethyl glycine) is a broad-spectrum systemic herbicide recommended for use in eucalyptus cultivation on the post-emergence of weeds using direct spray-jet applications (Amarante et al., 2002). This herbicide inhibits the 5-enolpyruvyl-3-phosphate synthase (EPSPS) enzyme and prevents the production of aromatic amino acids phenylalanine, tyrosine and tryptophan, which are essential for the continuity of protein synthesis in plants. Thus, plant death is associated with failure to produce compounds that derive from the shikimic acid route, which causes deregulation in the carbon flux and reduces protein synthesis (Bradshaw et al., 1997; Velini et al., 2011).

Glyphosate can cause damage in eucalyptus plants when in direct contact with the drift or even by root exudation of adjacent plants to the crop. Rodrigues et al. (1982) found that glyphosate-treated wheat plants exhibited ${ }^{14} \mathrm{C}$-glyphosate exudation into the soil with its consequent absorption and translocation by nearby grown corn plant roots, which ended up having ${ }^{14} \mathrm{C}$-glyphosate in all their tissues.

Eucalyptus plantations generally occur in areas formerly formed by pastures, and therefore grass species are among the main weeds present in these production areas, in which Brachiaria decumbens may be highlighted.

B. decumbens has fast establishment, good tolerance to soils with low fertility and high competition with invasive plants. It can also represent a contact form for glyphosate with eucalyptus plants through root exudation, by roots in direct contact with the crop, and also an indirect form of crop's intoxication in the field (Tuffi Santos et al., 2005). According to Tuffi Santos et al. (2005), ${ }^{14} \mathrm{C}$-glyphosate was found in eucalyptus plants grown in the same signalgrass vase treated with the herbicide, regardless of soil texture, clone or evaluation period. There was root exudation of glyphosate by the weed and later absorption via roots by the eucalyptus plants.

Knowledge on glyphosate herbicide in eucalyptus plants is relevant, since its direct and indirect effects still need to be understood (Tuffi Santos et al., 2008). Therefore, the objective of this study was to evaluate the effects of glyphosate on the initial development of Eucalyptus urograndis (clone 144) after applying the herbicide on Brachiaria decumbens plants cultivated in coexistence.

\section{MATERIAL AND METHODS}

Two experiments were carried out simultaneously between October 2014 and January 2015 in a greenhouse with average temperature of $25^{\circ} \mathrm{C}$ and $60 \%$ humidity. In the first experiment, quantification of glyphosate, aminomethylphosphonic acid (AMPA) and shikimic acid were determined, and in the second experiment the effects of the treatments on the development of eucalyptus plants were evaluated.

In both experiments (in the same vases), Eucalyptus urograndis clone 144 seedlings were planted with approximately $30 \mathrm{~cm}$ height and Brachiaria decumbens (18 plants) seeds were then sown to create a competing system. The vases contained five liters of soil that had the following physical and chemical characteristics at the end of the experiment: 303,86 and 611 g.dm ${ }^{-3}$ of clay, silt and sand; $\mathrm{pH}\left(\mathrm{CaCl}_{2}\right)=5.0 ; \mathrm{M} . \mathrm{O} .=11 \mathrm{~g} \mathrm{dm}^{-3} ; \mathrm{P}($ resin $)=15 \mathrm{mg} \mathrm{dm}^{-3}$; $\mathrm{Al}^{3+}=0$ mmolc dm ${ }^{-3} ; \mathrm{H}+\mathrm{Al}=41$ mmolc $\mathrm{dm}^{-3}$; $\mathrm{K}+=0.2 \mathrm{mmolc} \mathrm{dm}^{-3} ; \mathrm{Ca}^{2+}=16 \mathrm{mmolc} \mathrm{dm}^{-3}$; $\mathrm{Mg}^{2+}=6$ mmolc $\mathrm{dm}^{-3} ; \mathrm{SB}=22$ mmolc $\mathrm{dm}^{-3}$; CTC (T) $=63 \mathrm{mmolc} \mathrm{dm}^{-3} ; \mathrm{S}=33 \mathrm{mg} \mathrm{dm}^{-3}$; and V\% $=35$. The eucalyptus planting and the brachiaria sowing occurred on October 28 ${ }^{\text {th }}, 2014$.

The experiments were installed in a completely randomized design with four replicates, each one being composed of one vase. A $3 \times 3$ factorial scheme was used, where factor A corresponded to two doses of the 
herbicide (720 $\mathrm{g}$ and ha $\mathrm{a}^{-1}$ and $1,440 \mathrm{~g}$ and $\mathrm{ha}^{-1}$ ) and a control treatment (without application), and factor B to the collection sites of the eucalyptus plant leaves (lower, upper and pointer).

The herbicide was applied 50 days after planting eucalyptus and sowing the $B$. decumbens. For this, a stationary nozzle equipped with four XR11002VS tips spaced $0.5 \mathrm{~m}$ apart and placed at $0.5 \mathrm{~m}$ height in relation to the eucalyptus plants was used. The working pressure was $2.0 \mathrm{kgf} \mathrm{cm}^{-2}$, with a velocity of $3.6 \mathrm{~km} \mathrm{~h}^{-1}$ and a consumption of $200 \mathrm{~L} \mathrm{ha}^{-1}$. The commercial product used to prepare the spray was Roundup Original ${ }^{\bullet}$ ( $480 \mathrm{~g} \mathrm{~L}^{-1}$ isopropylamine gliphosate salt and $360 \mathrm{~g}$ a.e. $\left.\mathrm{L}^{-1}\right)$. The application started at 10 a.m. and was finished at 1 p.m., with an average temperature of $27.3^{\circ} \mathrm{C}$ and an average relative humidity of $57.5 \%$.

The eucalyptus plants were protected with plastic bags during treatments' application and adhesive tape was placed at the base of the stem, thus ensuring that the spraying was performed only on $B$. decumbens plants. After the spray dried on the leaves of the target plants (approximately $30 \mathrm{~min}$ ), the plastic protection was taken off and the $B$. decumbens plants were separated from the eucalyptus plants by means of a paper sheet, so that no contact occurred between the plant shoots. Daily irrigation was performed through dishes placed under the vases after applying the treatments.

In the first experiment the initial evaluations were anticipated by the rapid glyphosate absorption by the plants when compared to the second experiment. All the eucalyptus plant leaves were collected at 5, 10 and 21 days after application (DAA). The plants were divided into three sections (lower, upper and pointer) for glyphosate, AMPA and shikimic acid quantification. After collection, the leaves were dried in a forced air circulation oven at $40{ }^{\circ} \mathrm{C}$ (to avoid degradation of the compounds) for five days, macerated in liquid nitrogen and then the contents of glyphosate, AMPA and shikimic acid were analyzed by high performance liquid chromatography and mass spectrometry (LC-MS/ MS). Extraction and quantification of the analyzed compounds was performed according to the method proposed by Gomes et al. (2015). The retention time of the compounds in the chromatographic column was: glyphosate $2.89 \mathrm{~min}$; AMPA $2.89 \mathrm{~min}$; and shikimic acid $2.95 \mathrm{~min}$.
In the second experiment, taking into account that glyphosate translocates to the meristematic regions, visual evaluations were only performed on eucalyptus plant pointers at 7,14 and 21 DAA using a percentage scale of scores, where " 0 " corresponds to no damage, and " 100 " as death of the plant, according to the Brazilian Weed Science Society (SBCPD, 1995). The eucalyptus plants were collected at 21 DAA. For the collection, the plants were cut in two parts: upper (from the half of the plant's height to the apex) and lower (from the half of the plant's height to the base). The material was then placed in an oven at $40^{\circ} \mathrm{C}$ for five days, finally being weighed to determine its dry mass.

The results of the evaluated compounds ( $\mu \mathrm{g} \mathrm{g}^{-1}$ ) concentrations, visual analysis and dry mass of the plants were submitted to variance analysis by the F-test, and the means compared by the Tukey test at 5\% probability by the SISVAR program (Ferreira, 2011).

\section{RESULTS AND DISCUSSION}

AMPA was not detected in eucalyptus plants at 5, 10 and 21 DAA of glyphosate in any of the treatments. This indicates that glyphosate was not metabolized in the plant. At 5 DAA, small glyphosate concentrations were found in eucalyptus plants after the application of $720 \mathrm{~g}$ e.a. ha $\mathrm{a}^{-1}$ on B. decumbens in the lower and pointer collections, and for the dose of 1,440 g e.a. ha ${ }^{-1}$ of glyphosate in all collections (Figure 1). However, no glyphosate concentrations were detected in the controls.

At 10 DAA, glyphosate levels were found to be lower than those found in samples collected at 5 DAA (Figure 1). The highest concentrations were observed in the application of 1,440 g e.a. ha ${ }^{-1}$. However, glyphosate was detected in all collections at the dose of $720 \mathrm{~g}$ e.a. ha ${ }^{-1}$, even at 21 DAA. It is observed that the collection of the lower part with an application of $720 \mathrm{~g}$ e.a. ha ${ }^{-1}$ of glyphosate presented higher herbicide concentration when compared to the other treatments, and the levels of the compound in the pointer collection had an increase in relation to the collection performed at $10 \mathrm{DAA}$.

It is possible to verify that the glyphosate transfer by direct contact between the roots in the ground occurred by anastomosis, just as observed by Tuffi Santos et al. (2008), and/or extravasation of the B. decumbens' plant tissue and cellular contents, with subsequent glyphosate absorption by eucalyptus. The glyphosate 


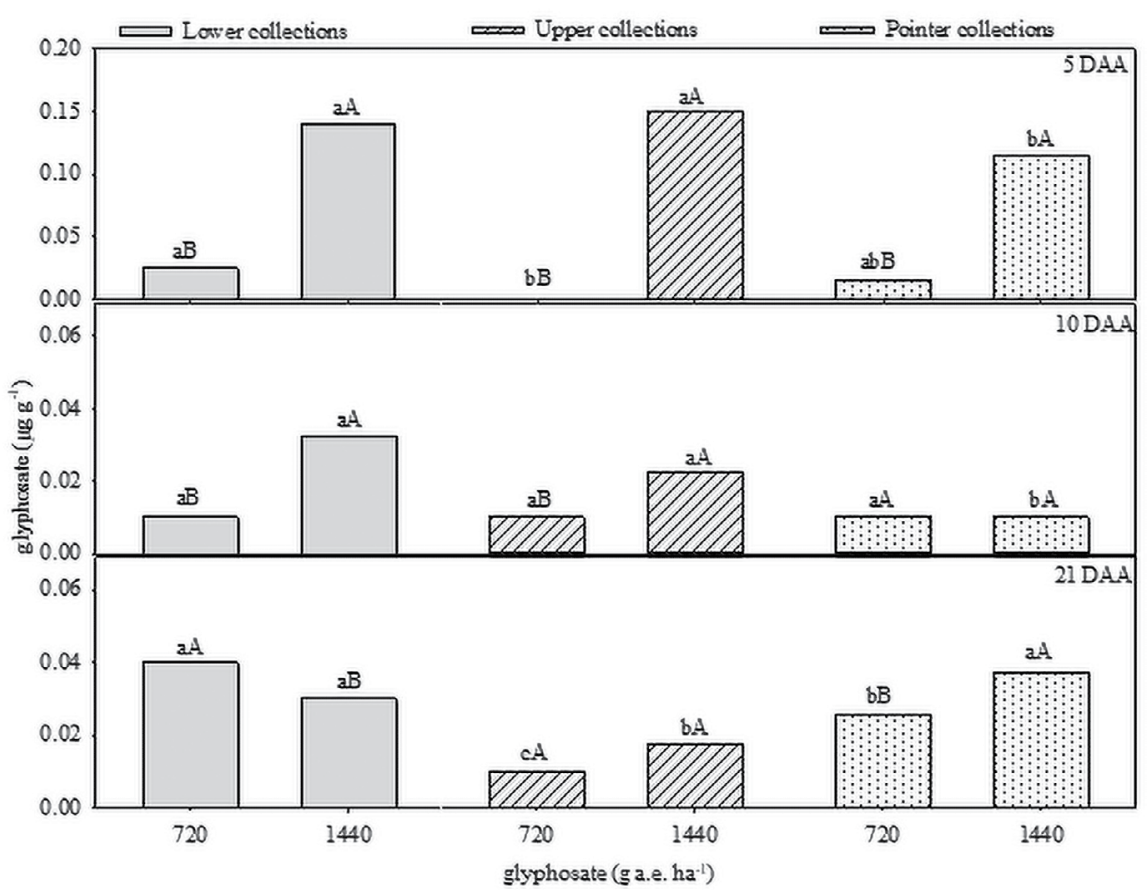

Figure 1. Glyphosate concentration in eucalyptus plants after the application of glyphosate in Brachiaria decumbens grown in the same vase. DAA: days after application. Means followed by the same capital letter within each collection mode and lower case in each applied dose do not differ among themselves by the Tukey test at $5 \%$ probability. CV (\%): 5 DAA, 20.22; 10 DAA, 49.93; 21 DAA, 28.39.

root exudation by plants that received the application and root absorption by adjacent plants have been reported in other works (Machado et al., 2009; Tuffi Santos et al., 2005; Tuffi Santos et al., 2008).

The results of this research demonstrate that glyphosate application for controlling weeds adjacent to a eucalyptus crop can be harmful, because the observed glyphosate transfer can cause phytointoxication in the crop and even present a decrease in productivity.

The highest shikimic acid concentration was observed in the upper part of the eucalyptus plants, even for the controls (Figure 2). This result can be justified by the fact that plants present a higher metabolic rate near its growth points. According to Croteau et al. (2000) and Dangl et al. (2000), sunlight intensity can have a direct impact on shikimic acid levels in plants, because the pathway provides intermediates used to synthesize flavonoids and other pigments to protect against UV-B radiation.

No increase in shikimic acid concentrations was observed in the different treatments in relation to the control, independent of the evaluation period (Figure 2). Several authors reported an increase in the accumulation of shikimic acid after glyphosate application (Buehring et al., 2007; Feng et al., 2004; Harring et al., 1998; María et al., 2006; Nandula et al., 2007; Orcaray et al., 2010; Petersen et al., 2007; Reddy et al., 2010; Reddy et al., 2008; Singh \& Shaner, 1998). However, in this study the eucalyptus plants did not accumulate the compound due to the low glyphosate concentrations found. According to Castro et al. (2016), the higher the glyphosate concentration found in the plant, the more shikimic acid is acylated.

Studies indicate that as the plant recovers from a sublethal application of glyphosate, the accumulated shikimic acid is metabolized by the plant and/or diluted with its resumed growth (Buehring et al., 2007).

There was no significant difference in the dry mass of the lower part of the eucalyptus plants in contact with the $B$. decumbens plants that received the glyphosate application. However, the dry mass of the lower part of 


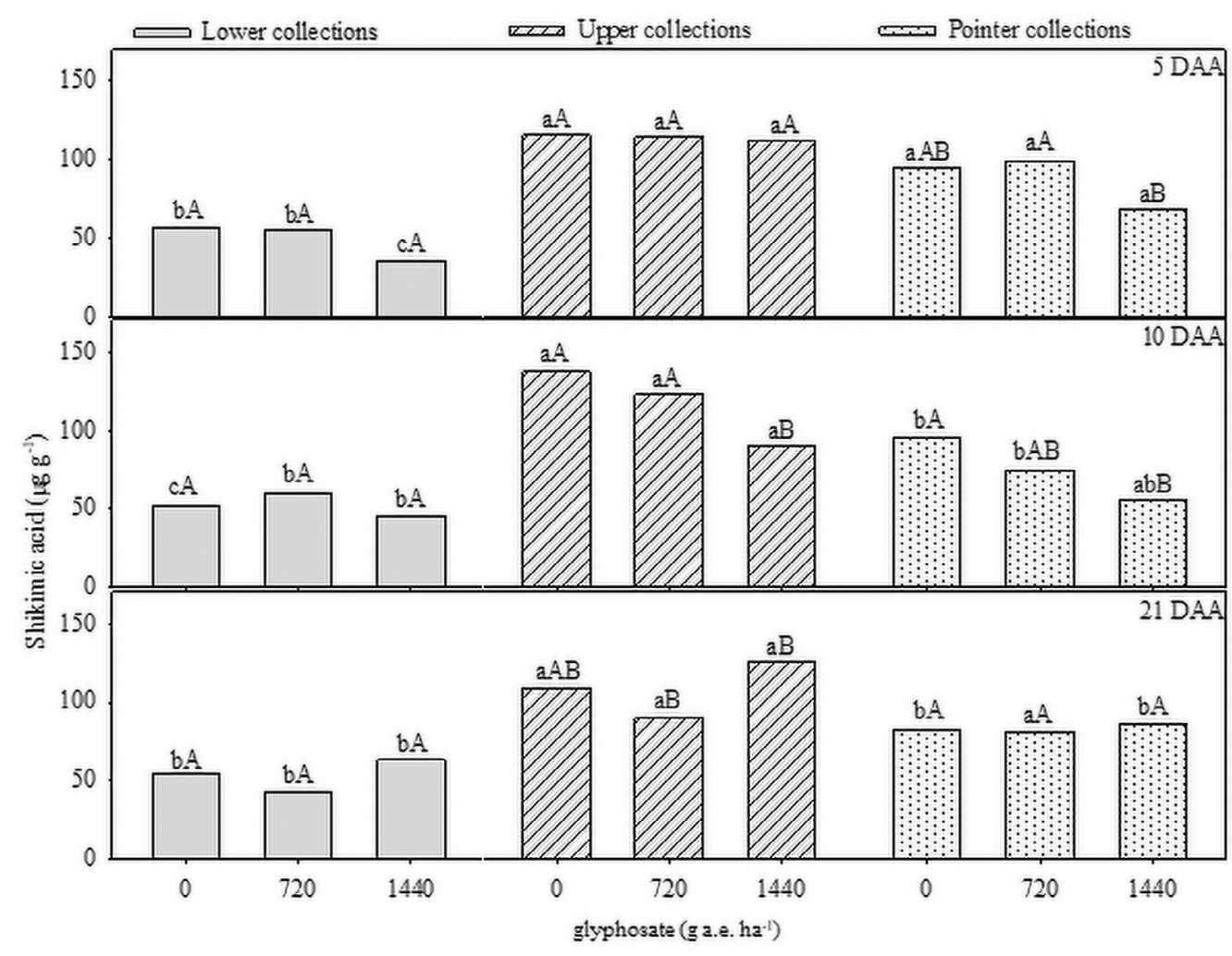

Figure 2. Shikimic acid concentration in eucalyptus plants after glyphosate application in Brachiaria decumbens cultivated in the same vase. DAA: days after application. Means followed by the same capital letter within each collection mode and lower case in each applied dose do not differ among themselves by the Tukey test at 5\% probability. CV (\%): 5 DAA, 18.52; 10 DAA, 19.98; 21 DAA, 16.09.

the eucalyptus plants was higher in relation to the upper part due to more mature stems and leaves (Table 1).

Table 1. Dry mass of eucalyptus plants in different collection locations and glyphosate application on Brachiaria decumbens plants.

\begin{tabular}{|c|c|c|}
\hline \multicolumn{3}{|c|}{ Dry mass (g) } \\
\hline Glyphosate doses & Upper & Lower \\
\hline Control & $4.43 \mathrm{bA}$ & $14.93 \mathrm{aA}$ \\
\hline 720 g e.a. ha-1 & $3.75 \mathrm{bA}$ & $17.17 \mathrm{aA}$ \\
\hline 1,440 g e.a. ha $^{-1}$ & $2.97 \mathrm{bA}$ & $14.81 \mathrm{aA}$ \\
\hline F Collection & $336.10^{\star}$ & \\
\hline F Application & $1.94^{\mathrm{ns}}$ & \\
\hline $\mathrm{F} \mathrm{Col} \times \mathrm{Apl}$ & $1.69^{\mathrm{ns}}$ & \\
\hline CV (\%) & 16.46 & \\
\hline
\end{tabular}

${ }^{\text {ns }}$ Non-significant at $5 \%$ probability by the Tukey test; ${ }^{*}$ significant at $5 \%$ probability by the F-test. Means followed by the same capital letter at each collection position and lower case at each application site do not differ from each other.
Eucalyptus plants showed low pointer intoxication levels after glyphosate application on $B$. decumbens plants (Table 2). The glyphosate doses of 720 and $1,440 \mathrm{~g} \mathrm{ha}^{-1}$ presented $5.25 \%$ and $6 \%$ of intoxication, respectively, in the evaluation at 7 DAA. There was an increase in the intoxication level at 14 and 21 DAA. The highest intoxication levels in eucalyptus plants were verified at 21 DAA with a glyphosate dose of 1,440 g e.a. ha ${ }^{-1}$. It should be noted that the intoxication percentage only refers to the damage caused in the pointers, which shows low intoxication levels for the plant. According to Tuffi Santos et al. (2007), eucalyptus plants with initial intoxication within the ranges of 6-10\% did not have their growth reduced by the herbicide at 180 DAA when compared to the control, considering the total shoot of the plant. A reduction in the total dry mass of the eucalyptus plants was only observed with the glyphosate application of 1,440 g e.a. ha ${ }^{-1}$ on the brachiaria (signal) grass. 
Table 2. Visual intoxication evaluation of the eucalyptus plants' top 7, 14 and 21 days after application and dry mass of eucalyptus plants after glyphosate application on Brachiaria decumbens plants.

\begin{tabular}{lcccc}
\multicolumn{1}{c}{ Treatments } & 7 DAA & 14 DAA & 21 DAA & Total weight (g) \\
\hline Control & $0.0 \mathrm{~B}$ & $0.0 \mathrm{~B}$ & $0.0 \mathrm{~B}$ & $19.36 \mathrm{AB}$ \\
\hline 720 g e.a. ha $^{-1}$ & $5.3 \mathrm{~A}$ & $6.5 \mathrm{~A}$ & $8.3 \mathrm{~A}$ & $20.92 \mathrm{~A}$ \\
\hline 1,440 g e.a. ha ${ }^{-1}$ & $6.0 \mathrm{~A}$ & $8.0 \mathrm{~A}$ & $10.0 \mathrm{~A}$ & $17.78 \mathrm{~B}$ \\
\hline F & $81.00^{*}$ & $56.61^{*}$ & $77.49^{*}$ & $4.96^{*}$ \\
CV $(\%)$ & 19.37 & 23.39 & 19.95 & 7.28 \\
\hline
\end{tabular}

* Significant at $5 \%$ probability by the F-test. DAA: days after application. Means followed by the same capital letter in the column do not differ from each other.

\section{CONCLUSIONS}

In general, glyphosate has the potential to cause a decrease in eucalyptus productivity, and the herbicide doses used in this study are associated with doses used in field applications. It was possible to observe the death of $B$. decumbens plants at the end of the experiment, regardless of the implemented dose. Thus, further studies are needed to characterize a dose that is able to control Brachiaria grass without causing damage to eucalyptus plants.

Eucalyptus plants co-living with $B$. decumbens that received glyphosate application absorbed the herbicide. Detection of low glyphosate levels in eucalyptus plants only promoted mild intoxication in the pointer leaves. Non-detection of AMPA demonstrates that absorbed glyphosate was not metabolized by the eucalyptus plants. The glyphosate application at a dose of 1,440 g e.a. ha ${ }^{-1}$ in $B$. decumbens plants living with eucalyptus causes reduced eucalyptus dry mass.

\section{ACKNOWLEDGMENTS}

To the Graduate Program in Agronomy/Plant Protection of Universidade Estadual Paulista Júlio de Mesquita Filho, Botucatu campus, and the Núcleo de Pesquisas Avançadas em Matologia (Nupam) for the research support, and the Coordenação de Aperfeiçoamento de Pessoal de Nível Superior (Capes) for the grant awarded.

\section{SUBMISSION STATUS}

Received: 10 Nov., 2016

Accepted: 6 June, 2018

\section{CORRESPONDENCE TO}

\section{Edicarlos Batista Castro}

Universidade Estadual Paulista Júlio de Mesquita Filho (Unesp), Proteção Vegetal,

Rua Dr. José Barbosa de Barros, 1.780, CEP 18610-307, Botucatu, SP, Brasil

e-mail: castroeb@hotmail.com

\section{REFERENCES}

Amarante OP Jr, Santos TCR, Brito NM, Ribeiro ML. Glifosato: propriedades, toxicidade, usos e legislação. Quimíca Nova 2002; 25(4): 589-593. 10.1590/S010040422002000400014

Bradshaw LD, Padgette SR, Kimball SL, Wells BH. Perspectivas sobre a resistência ao glifosato. Weed Technology 1997; 11(1): 189-198.

Buehring NW, Massey JH, Reynolds DB. Shikimic acid accumulation in field-grown corn (zea mays) following simulated glyphosate drift. Journal of Agricultural and Food Chemistry 2007; 55(3): 819-824. 10.1021/jf062624f

Castro EB, Carbonari CA, Velini ED, Belapart D, Gomes GLGC, Ronei B. Absorção, translocação e efeitos metabólicos do glyphosate em plantas de eucalipto. Scientia Forestalis 2016; 44(111): 719-727. 10.18671/ scifor.v44n111.18

Costa AGF, Alves PLCA, Pavani MCMD. Períodos de interferência de trapoeraba (Commelina benghalensis Hort.) no crescimento de eucalipto (Eucalyptus grandis W. Hill ex. Maiden). Revista Árvore 2004; 28(4): 471-478. 10.1590/S0100-67622004000400001

Croteau R, Kutchan TM, Lewis NG. Natural products (secondary metobolites). In: Buchanan BB, Gruissem $\mathrm{W}$, Jones RL, editors. Biochemistry and molecular biology of plants. Rockville: American Society of Plant Physiologists; 2000. p. 1250-1319.

Dangl JL, Dietrich RA, Thomas H. Senescence and programmed cell death. In: Buchanan BB, Gruissem 
W, Jones RL, editors. Biochemistry and molecular biology of plants. Rockville: American Society of Plant Physiologists; 2000. v. 24. p. 1044-1100.

Feng PCC, Tran M, Chiu T, Sammons RD, Heck GR, Cajacob CA. Investigations into glyphosate-resistant horseweed (Conyza canadensis): retention, uptake, translocation, and metabolism. Weed Science 2004; 52(4): 498-505. 10.1614/WS-03-137R

Ferreira DF. Sisvar: a computer statistical analysis system. Ciência e Agrotecnologia 2011; 35(6): 1039-1042. 10.1590/ S1413-70542011000600001

Gomes GLGC, Carbonari CA, Velini ED, Trindade MLB, Silva JRM. Extraction and simultaneous determination of glyphosate, AMPA and compounds of the shikimic acid pathway in plants. Planta Daninha 2015; 33(2): 295-304. 10.1590/0100-83582015000200015

Harring T, Streibig JC, Husted S. Accumulation of shikimic acid: a technique for screening glyphosate efficiency. Journal of Agricultural and Food Chemistry 1998; 46(10): 4406-4412. 10.1021/jf9802124

Indústria Brasileira de Árvores - IBÁ. Relatório IBÁ 2015. São Paulo; 2015 [cited 2016 May 9]. Available from: http://bit.ly/2WPxLWT

Machado AFL, Ferreira LR, Tuffi Santos LD, Santos JB, Ferreira FA, Viana RG. Absorção, translocação e exsudação radicular de glyphosate em clones de eucalipto. Planta Daninha 2009; 27(3): 549-554. 10.1590/ S0100-83582009000300016

María N, Berrecil AM, Garcia-Plazaola JI, Hernández A, Felipe MR, Fernández-Pascual M. New insights on glyphosate mode of action in nodular metabolism: role of shikimate accumulation. Journal of Agricultural and Food Chemistry 2006; 54(7): 2621-2628. 10.1021/jf058166c

Nandula VK, Reddy KN, Rimando AM, Duke SO, Poston DH. Glyphosate-resistant and-susceptible soybean (Glycine max) and canola (Brassica napus) dose response and metabolism relationships with glyphosate. Journal of Agricultural and Food Chemistry 2007; 55(9): 35403545. 10.1021/jf0635681

Orcaray L, Igal M, Marino D, Zabalza A, Royuela M. The possible role of quinate in the mode of action of glyphosate and acetolactate synthase inhibitors. Pest Management Science 2010; 66(3): 262-269. 10.1002/ps.1868

Petersen IL, Hansen HCB, Ravn HW, Sorensen JC, Sorensen H. Metabolic effects in rapeseed (Brassica napus L.) seedlings after root exposure to glyphosate. Pesticide Biochemistry and Physiology 2007; 89(3): 220229. 10.1016/j.pestbp.2007.06.009
Reddy KN, Bellaloui N, Zablotowicz RM. Glyphosate effect on shikimate, nitrate reductase activity, yield, and seed composition in corn. Journal of Agricultural and Food Chemistry 2010; 58(6): 3646-3650. 10.1021/ jf904121y

Reddy KN, Rimando AM, Duke SO, Nandula VK. Aminomethylphosphonic acid accumulation in plant species treated with glyphosate. Journal of Agricultural and Food Chemistry 2008; 56(6): 2125-2130. 10.1021/ jf072954f

Rodrigues JJV, Worsham AD, Corbin FT. Exudation of glyphosate from wheat (Triticum aestivum) plants and its effects on interplanted corn (Zea mays) and soybeans (Glycine max). Weed Science 1982 [cited 2019 May 16]; 30(3): 316-320. Available from: http://bit.ly/2YBpJlg

Singh BK, Shaner DL. Rapid determination of glyphosate injury to plants and identification of glyphosate-resistant plants. Weed Technology 1998 [cited 2019 May 16]; 12: 527-530. Available from: http://bit.ly/2VqNR85

Sociedade Brasileira da Ciência das Plantas Daninhas - SBCPD. Procedimentos para instalação, avaliação e análise de experimentos com herbicidas. Londrina; 1995.

Tiburcio RAS, Ferreira FA, Paes FASV, Melo CAD, Medeiros WN. Crescimento de mudas de clones de eucalipto submetidos à deriva simulada de diferentes herbicidas. Revista Árvore 2012; 36(1): 65-73. 10.1590/ S0100-67622012000100008

Tuffi Santos LD, Ferreira FA, Barros NF, Siqueira CH, Santos IC, Machado AFL. Exsudação radicular do glyphosate por Brachiaria decumbens e seus efeitos em plantas de eucalipto e na respiração microbiana do solo. Planta Daninha 2005; 23(1): 143-152. 10.1590/S010083582005000100017

Tuffi Santos LD, Meira RMSA, Ferreira FA, Sant'AnnaSantos BF, Ferreira LR. Morphological responses of different eucalypt clones submitted to glyphosate drift. Environmental and Experimental Botany 2007; 59(1): 11-20. 10.1016/j.envexpbot.2005.09.010

Tuffi Santos LD, Santos JB, Ferreira FA, Oliveira JA, Bentivenha S, Machado AFL. Exsudação radicular de glyphosate por Brachiaria decumbens e seus efeitos em plantas de eucalipto. Planta Daninha 2008; 26(2): 369374. 10.1590/S0100-83582008000200013

Velini ED, Carbonari CA, Trindade MLB, Gomes GLGC, Meschede DK, Duke SO. Modo de ação do glyphosate. In: Velini ED, Carbonari CA, Meschede DK, Trindade MLB, editors. Glyphosate: uso sustentável. Botucatu: Fepaf, 2011. p. 39-66. 